断面内二次流を考慮した分散係数に関する研究

\title{
A Study on Longitudinal Dispersion Coefficients in Open Channel Considering
}

\section{Secondary Flow Effects -}

$\begin{array}{ccc}\text { 大阪大学工学部 } & \text { 正員 室田 明 } \\ \text { 大阪大学大学院 学生員 } \bigcirc \text { 李 吉永 }\end{array}$

\section{1.はじめに}

河川の上流において流入した放射性物質などの污染物質がその下流において如何なる時間的, 空間的分布 を呈するかを予測するてとは水質工学上極めて重要である。従来から污染物質の分散機構解明のため多くの 研究がなされているが，その場合の污染物質の拡散状態を表現する重要なパラメーターは繸方向分散係数 $D$ である (以後, 簡単に分散係数という)。てのような分散係数に対して, Taylor ${ }^{(1)}$ は長いまっすぐな円 管中の分散機構を 1 次元分散方程式で表わし，E1der (2) はさらに Taylor の考光を無限に広い 2 次元開水路 に拡張し，対数速度分布を持つ流れを仮定して縦方向の分散に鉛直方向の速度変化のみを考虑した。一方， Fisher ${ }^{(3)}$ は自然河川や㬰験用開水路について, 流れが 3 次元的なため主流の横断方向の速度の不均一性が鉛 直方向の変化に比してはるかに大きく分散に寄与すると考元，てれを実験によって確めた。その後，道上・ 村本・伊丹(4)もFischerの考元方に沿った分散に関する研究を発表している．また福岡(5) は蛇行水路におけ る分散研究で bend そよって生ずる主流の横断流速分布もその結果生ずるらせん流によって無次元分散係数は 等価な直線流の分散係数に比し著しく大であるととを示した。一方, 以前著者の 1 人 $^{(6)}$ が発表したように， トレーサー染料雲の拡散挙動を詳細に観察すれば, 染料雲の前後端部においてあたかも手を開いたように複 数の縦縞を形成しながら移流する現象（てれをFingering 現象と称する）がみられる。乙れは開水路特有の 現象であると考えられ，ての現象を断面内二次流と関連させれば分散機構の理解に有効な知識を与えるであ ろう.

本研究では従来の乱れセン断効果による分散解析とは異なり, Fingering 現象と断面内二次流との関係に もとづき二次流の特性を定量的に分析し，それが分散現象におよはすす影響をパラメーターの多重回帰分析法 により明らかにすべく考察を加える.

\section{2. 実験およびその結果}

実験に用いた水路は長さ $20 \mathrm{~m}$, 幅 $0.5 \mathrm{~m}$, 高さ $0.32 \mathrm{~m}$ のアクリル樹脂製の可変勾配水路である. 予備実 験で Fingerの発生個数を把握した後, 水理条件を決定した。また移動流域においてセン断効果による濃度一 時間曲線が歪まされるととを考虑し，Taylor 分散域に対応できるようにトレーサーの投入方法に関しても十 分検討した後に実験を行なった。実験諸元は表一 1 亿示す。ケース番号で $S_{n}, H, U_{a}$ はそれぞれ形状比 $(B$ $/ H)$, 等流水深, 断面平均流速である. 流量は $1.7 \mathrm{l} / \mathrm{sec} \sim 7 \mathrm{l} / \mathrm{sec}$, 水路勾配 $I$ は $(0.2 \sim 1.5) \times 10^{-4}$

\section{表一 1 水理諸量および実験結果}

\begin{tabular}{|c|c|c|c|c|c|c|c|c|c|c|c|c|}
\hline $\begin{array}{c}\text { Case } \\
\text { Sn-H-Ua }\end{array}$ & $\begin{array}{l}u^{*} \\
(1)\end{array}$ & $\begin{array}{l}\mathrm{Fr} . \\
(2)\end{array}$ & $\begin{array}{l}\text { Re. } \\
\text { (3) }\end{array}$ & $\begin{array}{c}f \times 10^{-3} \\
(4)\end{array}$ & $\begin{array}{l}\text { Ug } \\
\text { (5) }\end{array}$ & $\begin{array}{c}\Delta \mathrm{U} / \mathrm{Un} \\
(6)\end{array}$ & $\begin{array}{r}\text { u/Uo } \\
(7)\end{array}$ & $\begin{array}{c}\mathrm{u}^{\star} / \mathrm{Ua} \\
(8)\end{array}$ & $\begin{array}{c}n \\
(9)\end{array}$ & $\begin{array}{c}\mathrm{D} / \mathrm{u}^{\star} \mathrm{H} \\
(10)\end{array}$ & $\begin{array}{l}\mathrm{D} / \Delta \mathrm{UL} \\
(11)\end{array}$ & $\begin{array}{l}\mathrm{L} \\
\text { (12) }\end{array}$ \\
\hline $5-10-14$ & 0.802 & 0.14 & 13903 & 5.02 & 14.63 & 0.063 & 0.102 & 0.057 & 94.4 & 13.5 & 2.59 & 32 \\
\hline $6-8-14$ & 0.697 & 0.16 & 11538 & $4.0 \mathrm{n}$ & 14.94 & 0.056 & 0.101 & 0.052 & 90.4 & 15.6 & 2.70 & 31 \\
\hline $7-7-14$ & 0.897 & 0.16 & 10310 & 8.83 & 16.15 & 0.063 & 0.072 & 0.064 & 90.8 & 14.5 & 2.61 & 30 \\
\hline $7-7-10$ & 0.660 & 0.18 & 7630 & 9.07 & 12.46 & 0.066 & 0.073 & 0.066 & 93.6 & 20.0 & 3.43 & 30 \\
\hline$-7-7-5$ & 0.327 & 0.06 & 3820 & 8.39 & 7.50 & 0.063 & 0.075 & 0.065 & 65.0 & 28.8 & 3.74 & 31 \\
\hline$[10-5-14]$ & 0.759 & 0.20 & 6951 & 5.88 & 15.08 & 0.059 & 0.106 & 0.054 & 80.0 & 21.1 & 3.00 & 30 \\
\hline
\end{tabular}


の範井である.濃度は上流端（ $x=0 ）$ 加色素トレーサー（メチルバイオレット）を瞬間面源として投入し， 下流 $10 \mathrm{~m}, 15 \mathrm{~m}$ の 2 断面において半水深点で濃度の時間変化をレーザー濃度計により測定した。流速分布の 測定は等流状態を作ったのちに，水路上流端から $15 \mathrm{~m}$ 断面で水素気泡列を発生させ，乙れを連続撮影する方 法で行なった。測定は横方向に $2 \mathrm{~cm}$ 間隔で写真から得られる 0.3 秒毎の流下方向 $(x)$ 瞬間流速成分 $u_{i}(y$, $z)$ を読みとり, 各々の測定地点におけるアンサンブル平均流速 $U(y, z)$ と乱れ強度 $u(y, z)$ を求めた. また表 -1 で, 摩擦速度 $u^{*}$, フルード数 $F_{r}$ ，レイノルズ数 $R_{e}$ ，および摩擦係数 $f$ 等の算定式は表一 1 の下 部に表示した通りである。欄(5)〜（12）まではそれぞれ実験により求めた主流平均流速 $U_{0}$, 高速縞と低速縞 との速度偏差の無次元量 $\Delta U / U_{0}$ ( 以後, 便宜上断面内二次流の強度と称する), 乱れ強度 $u / U_{0}$, 摩擦速度 の無次元量 $u * / U_{a}$, 分散係数 $D$, 無次元分散係数 $D / u^{*} H$, 断面内二次流の特性量を用いて無次元化した分 散係数 $D / \Delta U \cdot L$ おょび混合特性長 $L$ である. 次に本論文に用いる諸流速に関して次のように定義する.

（1）断面平均流速； $U_{a}=Q / A,(2)$ 横断方向平均流速 $U_{0}(y) ;(y / H=0.86$ 点の平均流速, (3). 任意地点の 時間平均流速; $U(y, z)=\frac{1}{N} \sum_{i=1}^{N} u_{i}(y, z),(4)$ 。平均乱往度 ; $u(y, z)=\sqrt{\frac{1}{N} \sum_{i=1}^{N}\left[u_{i}(y, z)-U(y, z)\right]^{2}}$, (5). 断面内速度偏差; $\Delta U=$ 高速縞速度 $U_{p}$ 一低速縞速度 $U_{L}$. こてに, $N$ はサンプル数であり, 今回は $N=25$ とした.

\section{3・二次流の特性量の決定およびその評価}

Fingering 現象について, 断面内流動 に励起されて生じた Finger の数あるい は縦縞の個数 $N_{f}$ と形状比 $(B / H)$ との 間には強い相関がみられ，次式の関係 が成立する。

$$
N_{f}=\frac{1}{2}(B / H)
$$

また Fingering 現象の安定性に関して水 路の形状比との関係を検討した. 実験 より $B / H$ の值が偶数の場合Finger の発 生個数は一定となるが, $B / H$ が奇数の 場合にはFinger の発生個数は必ずしも 一定ではない。例えば $B / H=5$ の場合 Fingerの個数は 2 あるいは 3 となる。 すなわち $B / H$ の值が偶数の場合は断面

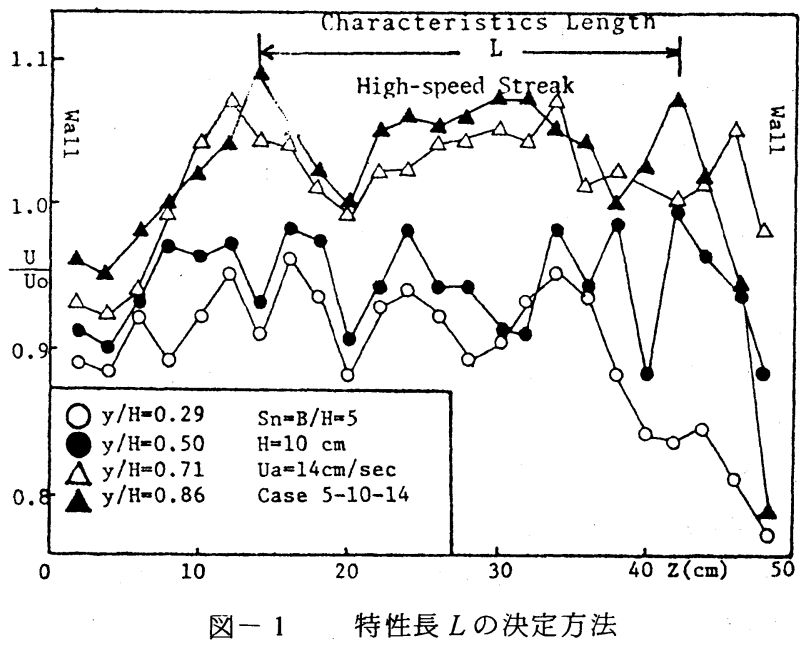
内二次流の発生状態は安定であり，奇数の場合には不安定であると考えられる.

$3-1$. 断面内二次流の特性量の決定

断面内二次流の特性量を決定するため主流速度 $U / U_{0}$ の横方向分布を図- 1 亿示す. 文献 $(6)$ と同様に $U$ 儿。 の分布は横方向に非一様性を呈しており，てのような非一様性流速分布は開水路にみられる乱れ変動に も増して染料の分散現象に大さな影響をおよばすと考えられる。断面内二次流の特性量として下記のような諸 量を考える.まず断面内二次流の強度の指標として主流速度の平均值からの偏差 $\Delta U$ を採用し, 壁面近傍を

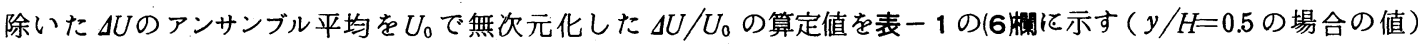
. 次に分散係数 $D$ 亿関与すると考元られる横方向特性長 $L$ は図 - 1 のように, $U / U_{0}$ の横方向分布で水深 $y$ $/ H$ が $0.29 ， 0.50,0.71 ， 0.86$ のそれぞれに対応する最も壁面に近い高速縞発生点間の距離の平均値とした.

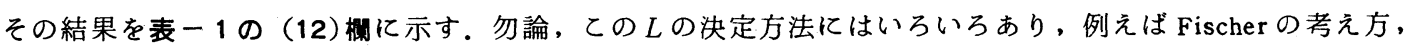
低速縞発生点間の距離および最大高速縞発生点から壁面までの距離などがあるが今回の特性長 $L$ は断面内

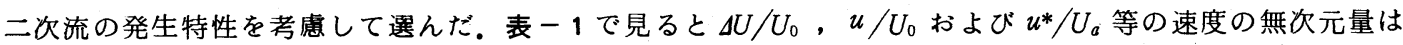
近似的に同一オーダーである。 また $L$ は $30 \sim 35 \mathrm{~cm}$ の範囲であり, 水深の $3.9 \sim 6.0$ 倍, 水路幅の約 0.6 
倍になる。

$3-2$. 特性量の評価

まず断面内二次流の発生特性に関する量を $B / H$ ( 形状比), 強度を 代表する量を $\Delta U / U_{0}$, 混合のスケールに関係する特性長を $L$ と各々定 義する. 図 -2 は $\Delta U / U_{0}$ と摩擦速度の無次元量 $u * / U_{a}$ との相関を図示 したものであり，両量間には密接な関係があるのがわかる，即ち， $u^{*} / U_{a}$ に対し， $\Delta U / U_{0}$ も線型的に増加している。乙てれは断面内二次流 の強度は一般的に表示される摩擦速度の無次元量と直接的な関係を持 っているととを示す。

また図ーア は $\Delta U / U_{0}$ と形状比 $B / H$ との関係を図示し たものである，全体的に， $B / H$ が增加する場合 $\Delta U /$ $U_{0}$ は減少する傾向がみられる。 また水深別の比較より ，断面内二次流の発生源は水路床にあると考元られる ・四中の点線は $y / H$ 亿対する全体平均值を取って表示 したものである.

次に，図一 4 は特性長 $L$ 亿対して断面内二次流の特 性を考慮した $L / H$ と $B / H$ との無次元スヶールの相関を 示したものである。図より $L / H$ と $B / H$ との相関性が高 いととがわかる。

以上のように検討した結果によると，断面内二次流 の特性流の間の相関性が高いととがわかった。特に断面 内二次流の強度 $\Delta U / U_{0}$ とセン断速度の無次元量 $u^{*} / U_{a}$

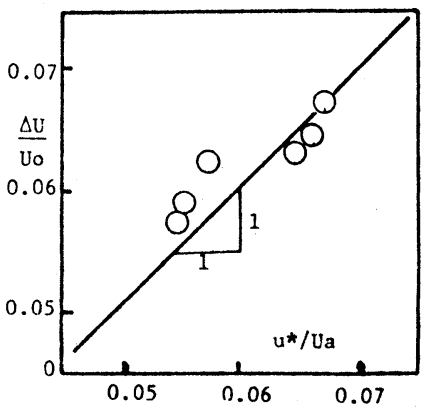
困-2 $\frac{\Delta U}{U_{0}}$ と $\frac{u^{*}}{U_{a}}$ との相関

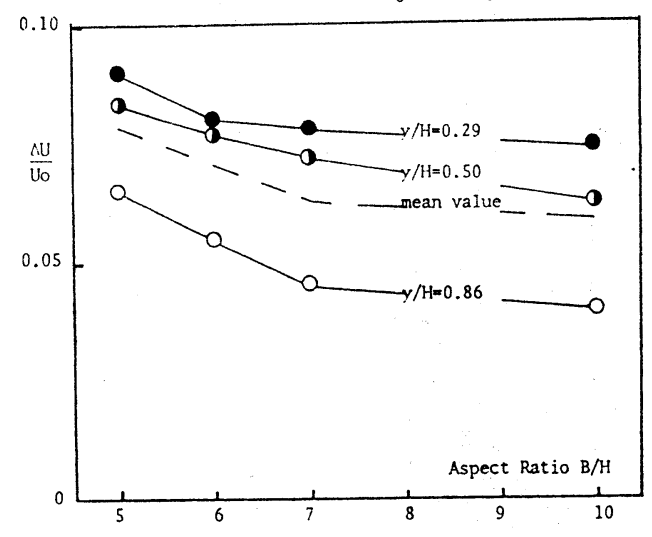

図-3 $\Delta U / U_{0}$ と $B / H$ との関係 との相関関係はこれからの分散解䣋のため重要である。よって 上記に定義した特性量を本論文の分散解析のために適用する。

\section{4. 二次流の特性量亡分散係数}

断面内二次流の特性が直接的に分散現象におよぼす影響に ついて考える. 分散係数は実測濃度一時間曲線からモーメン ト法によって算定しその結果を表ー1亿示した。それらの分 散係数に対して先に示した二次流の特性量がぞのような影響 を与えるかについて以下検討する。図ー5亿は既往の成果と 本実験結果に対して摩擦係数 $f$ を用いて無次元分散係数 $D /$ $u^{*} H$ と形状比 $B / H$ との関係を示した。また実験用開水路と自

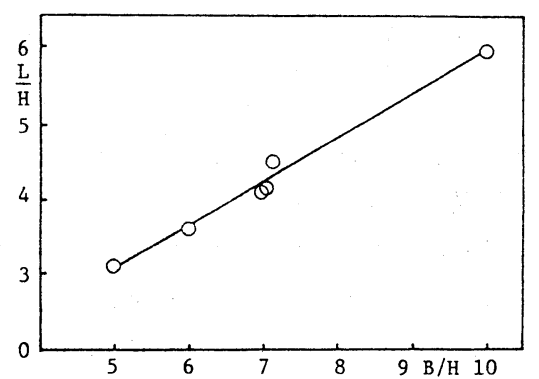

図一 4 特性長 $L$ の評価 然河川に至る広い範囲にわたって図示する方法を武みた。図中の実線および点線は $f$ を，点線の矩形は実験 用開水路と自然河川との境界を示す。眓加ら見ると, 全体的に $D / u^{*} H$ は $f$ 増加とともに $B / H$ に比例して 増加しており，fが大きくなる程変化率は急勾配となる。また自然河川と実験用開水路との関係については $, D / u^{*} H, f$ および $B / H$ との間の相関は実験用開水路の方が自然河川の方よりもばらつきが少なくなってい る. この原因は $f$ の変動範囲が自然河川の方が広いととによるものと推察される。また $D / u^{*} H$ の分布状態 が $f$ の線から多少ばらつくのは $f$ の決定法のあいまいさがその原因と考えられる。一方，図一 5 亿対する検 討の目的の 1 つは，分散係数を無次元化するときの分母に使用されるパラメーターを決定する問題である. 断面内セン断効果を横方向流速分布に着目して, $B u^{*}$ のパラメーターを用いて $D / B u^{*}$ と $B / H$ との関係を検 討して見ると図 -5 とは対照的に $D / B u^{*}$ の值と $B / H$ の值の間に一定な変化傾向をみるてとができない。一 方，Krishnappan ${ }^{(10)}$ などが横方向拡散係数に対しておてなった検討によると， $E_{z} / B u^{*}$ と $B / H$ の間には双曲 


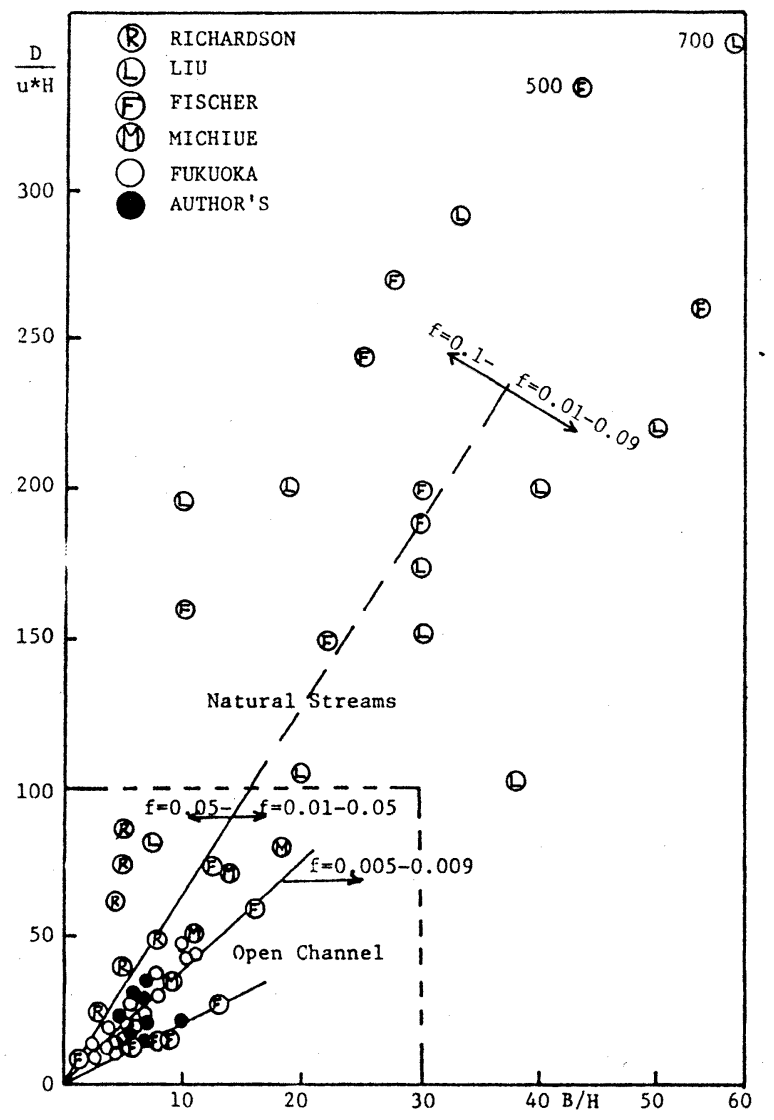

図-5無次元分散係数と形状比との関係

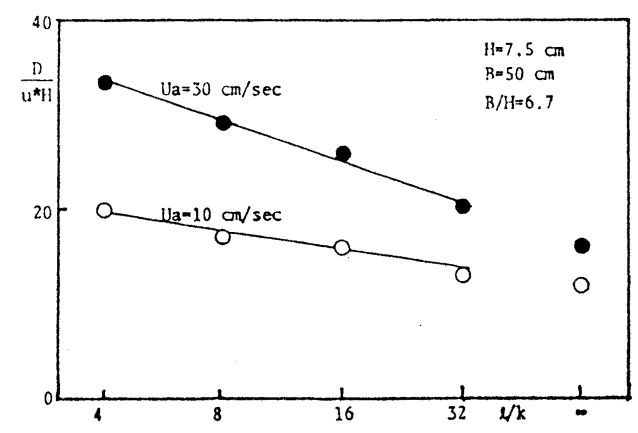

艮一 $6 U_{a}, \frac{l}{k}$ が変化する場合 $D / u^{*} H$

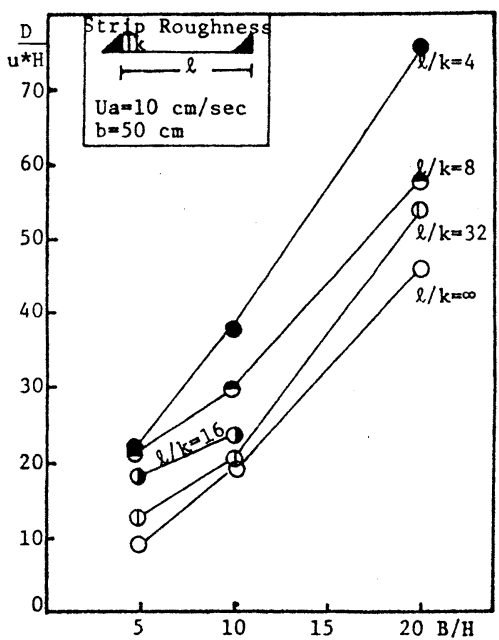

図一7 $\frac{D}{u^{*} H}$ と $\frac{B}{H}$ および $\frac{l}{k}$ との関係

線の関係が成立し。結局 $E_{z}=\alpha_{E} u * H$ となる。乙れに対し

分散係数 $D$ は二次流を考慮した場合も水路輻に関係があると推察できる.

次に図-6は $B / H$ が一定で, 流速と粗度が変化する場合において無次元分散係数と, 栈型粗度の高さと その間隔の比 $(l / k)$ との関係で示したものである。また図一6の関係を二次流と関連させて明らかにする ため図－7のように水路輻と流速が一定で, 粗度と水深が変化する場合の $D / u^{*} H, B / H$ およ゙ $l / k$ 相関 を示す．図によると，B/Hおよび粗度係数が増加する程，無次元分散係数 $D / u^{*} H$ は増加している．また同 一の形状比の場合には図 -6 と同樣 $l / k$ が小さい（粗度係数が大きい）方が $D / u^{*} H$ の值は大きくなる. 図一 6 と図-7より総合的に考えて, $B / H$ が一定の場合, 断面内二次流循環の効果は同じであるからそのとさの $D / u * H$ の增加は粗度の影響によって断面内二次流の強度が増加するためであると考えられる. てれは前述 したように二次流の発生源と粗度係数との関係による。また $B / H$ あるいは平均流速が増加する程 $D / u^{*} H$ も 增加するのは，断面内二次循環は污濁物質の混合を促進させ，それと同時に混合された污濁物質は断面平均 流速によって移流されるためと推察される。

\section{5. 分散係数の推定}

二次流の特性量と分散係数との関係について考察するてとは, 実用公式提示の目的よりもむしろスヶール の評価に対して意義があるものと考えられる。

\section{$5-1$ 次元解析}

理論的な解析に入る前に二次流と分散の間に定量的な表現を与えるためにはパラメーター解析が必要であ る.一樣長方形断面水路における分散係数に関係するパラメーターとしては断面平均流速, 水深, 水路幅 
, 摩擦速度, 密度 $\rho$, 粘性係数 $\mu$ などが考えられる。即ち，，

$$
D=F\left(U_{a}, H, B, u^{*}, \rho, \mu\right)
$$

いま, $u^{*}, H, \rho$ を基本量として選定すると(2)式は(3) 式のように無次元化される.

$$
\frac{D}{u^{*} H}=F\left(\frac{u^{*}}{U_{a}}, \frac{B}{H}, \frac{\rho u^{*} H}{\mu}\right)
$$

(3)式のレイノルズ項に対しては, 従来の経験的方法, 分散係数と相関性の検討, および断面内二次流の強度 との多重回帰分析による重相関係数の検討などから， $R_{e}$ 数は無次元分散係数に直接的な影響をおよはささな いと判断された。前述の $u^{*} / U_{a}$ と $\Delta U / U_{0}$ の相関（図－2）を考虑して(3)式を再整理すると(4)式のようになる.

$$
\frac{D}{u^{*} H}=F\left(\frac{u^{*}}{U_{a}}, \frac{B}{H}\right) \text { あるいは } \frac{D}{u^{*} H}=F\left(\frac{\Delta U}{U_{0}}, \frac{B}{H}\right)
$$

次に断面内二次流の特性量（ $L$ および $\Delta U)$ を用いて直接的に分散係数の推定を試みる.そのためには $D$ と $L$ および $\Delta U$ との関係を定式化する基本的な考元方を決定するてとが必要である。それを下記のよう亿設定する.

(1)。二次流の特性量と分散係数との関係にはスケールの概念を重視して考察を加える.

(2). 両者の関係を定式化する場合にはE1derの方式を導入して類推し，その結果から両者間の特性および 二次流の特性量が分散現象におよぼす特性を評価する。

上記の $(1),(2) よ り$,「開水路における断面内二次流を考虑した場合, 分散係数は二次流の特性長 $L$ と断面 内速度偏差 $\Delta U$ の積により表示する」，すなわち，

$$
D=\alpha_{s} L \cdot \Delta U
$$

(5)式の $\alpha_{s}$ を表一 1 の（11）欄に示し，その平均值は $\alpha_{s} \doteqdot 2.98$ である。また(5)式において図ー2〜図ー7まで を考えて形式的に表示すると次式のようになる.

$$
D=\alpha u^{*} H
$$

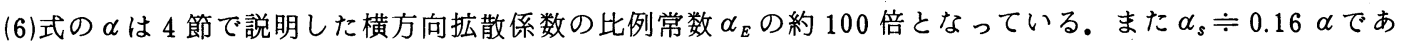
る. 表- 1 亿よると $B / H$ の值に比例して $\alpha_{s}$ も増加しているが, Elderの $\alpha$ 值は開水路における水路の形 状比にも関係なく一定な值をもつのが一般的な事実である。したがって結果的には E ld e r の方式と全く同 じ型式に䚻着するように見えても $L \Delta U て ゙$ 表示する分散公式は $u^{*} H$ で表示する式と根本的に考方方が異なる ・てれは Elder の $u^{*} H$ の中の $u^{*}$ は鈴直速度分布の代表量であり, 混合に関係する特性長は水深となるのに対 して, L UUに対する特性についての推論より， $\Delta U$ は横方向速度分布にもとづく横方向セン断効果を示して おり，Lは水深の効果よりも水路幅の影響を大きく受けているということである.

以上を総合的に評価すると， $D$ と $L \Delta U$ との関係は形式的には Elder 方式と同一となるが，現象的な面で考 えると二次流の特性量 $L$ および $\Delta U$ を導入するととはFischerの考元方に近いといいうるであろう.

$5-2$ 。実験式の決定およびその評価

5-1での考え方は実用的な面よりもスケールの概念を重視して考察した結果であるが，本項においては 4 節で分析した結果を中心に実用性を考虑して下記のように実験式の決定を試みた。

4 節により流速, 水深。水路幅, 粗度などと分散係数との相関がすべて直線的に変化しているてとがわかっ た。したがって重回帰分析を適用して変量間の相関を把握する必要がある。そのためててで(4)式を用いて次 式のような重回帰式を示す。

$$
\frac{D}{u^{*} H}=\beta_{0}+\beta_{1} \frac{u^{*}}{U_{a}}+\beta_{2} \frac{B}{H}
$$

ここに, $y=D / u^{*} H, \quad x_{1}=u^{*} / U_{a}, x_{2}=B / H$

(7)式の各相関係数を算定した結果を表一 2 亿示す．表一 2 によると無次元分散係数に対する $u * / U_{a}$ と $B / H$ の単相関係数の值は高く, $u^{*} / U_{a}$ と $B / H$ 間の単相関係数は低い。また偏相関係数も同じ傾向である. 
表一2. 諸相関係数の計算結果

\begin{tabular}{|c|c|c|c|c|c|c|c|}
\hline Reference & Coe. of Reg. & $\begin{array}{l}\text { Coe. of Simple } \\
\text { Corr. }\end{array}$ & $\begin{array}{l}\text { Coe.of Partial } \\
\text { Corr. }\end{array}$ & $\begin{array}{l}\text { Coe. of Multiple } \\
\text { Corr. }\end{array}$ & $\begin{array}{l}\text { Degrees of } \\
\text { Freedom }\end{array}$ & $\begin{array}{l}\text { Unbiasedness } \\
\text { Variance }\end{array}$ & $\begin{array}{l}\text { Variance } \\
\text { Rate }\end{array}$ \\
\hline$y=D / u * H$ & $\beta_{0}=-9.577$ & $R_{12}=0.342$ & $R_{12}^{\prime} \cdot y=-0.569$ & $R=0.949$ & $f_{R}=2$ & $\begin{array}{l}V_{R}=S_{R} / f_{R} \\
=3070.593\end{array}$ & $\begin{array}{l}F o=V_{R} / V_{e} \\
=103.930\end{array}$ \\
\hline $\mathrm{x}_{1}=\mathrm{u}^{*} / \mathrm{Ua}$ & $R_{1}=122.617$ & $R_{1} y=0.615$ & $R_{1} y_{2}=0.724$ & $\begin{aligned} \mathrm{R}^{2} & =0.9006 \\
& =90 \%\end{aligned}$ & $f_{e}=N-3=23$ & $\begin{array}{l}V_{\mathrm{e}}=\mathrm{S}_{\mathrm{e}} / \mathrm{f}_{\mathrm{e}} \\
=\quad 29.545\end{array}$ & \\
\hline$x_{2}=B / H$ & $B_{2}=2.458$ & $R_{2} y=0.889$ & $R_{2} y_{\cdot 1}=-0.916$ & & $f_{T}=N-1=25$ & & \\
\hline
\end{tabular}

$* *$ Coe. $=$ Cocfficient, Reg. $=$ Regression, Corr. $=$ Correlation

特认重相関係数 $R$ の值が高く, 高い有意性が認められ

る. また自由度 $F$ 分布から上側確率 $P$ が $0.5 \% \sim 5.0$ \%まで考虑してもモデル式から得られた分散比 $F_{0}$ は 103.9 で非常に良好なモデル式となると判断される. てれょり(7)式に表一2の結果を代入して再整理すする と下記のような実験式が得られる。

$$
\frac{D}{u^{*} H}=122.6 \frac{u^{*}}{U_{a}}+2.458 \frac{B}{H}-9.577
$$

(8)式を図ー8のような方法によって評価して見ると, 縦軸の実測無次元分散係数と横軸の実験式によるそれ とは検定直線によく一致している。したがって18)式を 開水路における断面内二次流を考虑して実用化した分

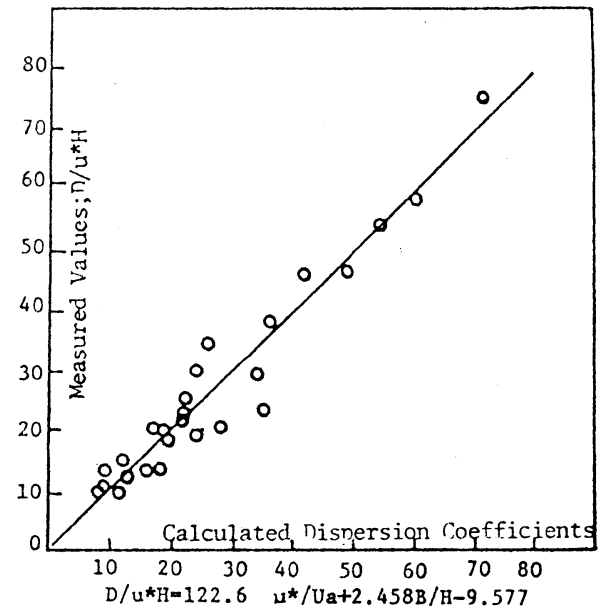

温-8 実験式の評価 散係数を推定するための実験式として提案したい。(8)式は流れの特性および水路の幾何学的特性を同時に考 慮して得られたという点で斬新さおよび重要性を持っている.

\section{6. 結論}

分散係数は乱れ構造とともに断面内二次流によっても強く影響されるてとが明らかになった。また，分散 係数と二次流との関係は試行的に(5)式で表示できるであろう。一方, 実用的には流速, 水深, 水路幅, 粗度 などの諸水理量を用いた実験式(8)を提案する.

最後に, 実験に際して熱心に協力して頂いた大阪大学大学院学生の福原輝幸氏, 小田勝也氏に深甚の謝意 を表する.

\section{参考文献}

(1) Taylor, G. I ; R.S.L., Vol . 223, Series A, 1954.

(2) Elder, J .W.; J.F.M., Vol . 5, No.4, 1959

(3) Fischer, H.B.; J .H.D., ASCE, Vol .93, No.HY6, 1967

（4）道上正規 - 村本嘉雄 - 伊丹正紀; 第 22 回水理講演会論文集, 1978

(5) 福岡捷二; 土木学会論文報告集, 第 200 号, 1972

（6）室田 明・中辻啓二・福原輝幸; 第 23 回水理講演会論文集, 1979

（7）室田 明·李 吉永; 土木学会第 34 回年次学術講演会概要集, 1979

(8) Miller,A.C. and E.V.Richardson ; J.H.D., ASCE, Vol. 100, No. HY 1, 1974

(9) Liu, H.; J.E.E.D., ASCE, Vol. 103, No. EE1, 1977

(10) Lau, Y.L. and B.G.Krishnappan ; J.H.D., ASCE, Vol.103, No. HY 10,1977 